\title{
Posudzovanie kvality odrazu pri salte vpred na základe časových charakteristík okamžitých síl na krivkách odrazu vo vertikálnych a horizontálnych rovinách v realizačnej fáze
}

\author{
Assessment of Bounce Quality in a Forward Somersault \\ on the Base of Time Characteristics of Immediate Forces \\ of Bounce in Vertical and Horizontal Plane
}

\author{
Rastislav Feč, Tibor Klaček
}

Fakulta športu, Prešovská univerzita v Prešove, Slovenská republika

\begin{abstract}
Abstrakt
$V$ príspevku sa zaoberáme hladaním možných ukazovatelov správnej techniky odrazu pri salte vpred skrčmo na základe vztahov medzi časovými charakteristikami okamžitých síl vo vertikálnych a horizontálnych rovinách v realizačnej fáze odrazu. Výskumný súbor tvorilo 13 študentov fakulty športu. Ako metódu pre hladanie vhodných ukazovatelov správnej techniky odrazu sme použili štatistickú významnost'p $\leq$ 0,05 Spearmanovho korelačného koeficientu medzi jednotlivými sledovanými pomermi a počtom bodov za prevedenie salta vpred. Predpokladali sme, že niektoré zo sledovaných časových charakteristík budú predstavovat možný ukazovatel'správnej techniky odrazu. Hypotéza sa nám potvrdila. Možnými ukazovatel'mi kvality odrazu, zoradené od najvýznamnejšieho, sú: premenná 4 (pomer času od dosiahnutia maximálnej sily vo vertikálnej rovine po ukončenie odrazu k celkovému času odrazu), premenná 6 (pomer času od dosiahnutia maximálnej sily vo vertikálnej rovine po ukončenie odrazu k času od dosiahnutia maximálnej sily v horizontálnej rovine po ukončenie odrazu), premenná 2 (čas od dosiahnutia maximálnej sily vo vertikálnej rovine po ukončenie odrazu).
\end{abstract}

\begin{abstract}
The paper deals with looking for potential indicators of correct technique of bounce concerning a tucked forward somersault on the base of relations between time characteristics of instantaneous forces in a vertical and horizontal plane in a realization phase of the bounce. Our test-group was created by 13 students of Faculty of Sport. We used statistical significance of Spearman correlation coefficients $p \leq 0,05$ as a method for judging whether or not a particular ratio of the impulses of forces in the vertical and horizontal plane represents a suitable indicator of correct technique of bounce. We assumed that some of the observed ratios will represent the potential indicator of correct technique of bounce. The hypothesis was confirmed. The potential indicators of bounce are the following: variable 4 (time frame since vertical force reached its maximum value to the end of jump to total time of bounce), variable 6 (time frame since vertical force reached its maximum value to the end of bounce to the time frame from when horizontal force reached its maximum value to the end of bounce), variable 2 (time frame since vertical force reached its maximum value to the end of bounce).
\end{abstract}

Klúčové slová: $\quad$ gymnastika, biomechanika, biomechanická analýza odrazu, salto vpred, dynamograf Key words: $\quad$ gymnastics, biomechanics, biomechanical analysis, front somersault, dynamograph

\section{Úvod}

Technika odrazu v gymnastike je dôležitým faktorom športovej výkonnosti. Dôsledkom odrazu vzniká letová fáza, ktorá sa riadi fyzikálnym zákonom zachovania pohybu tažiska, ktorý hovorí, že vnútornými silami nie je možné zmenit trajektóriu tažiska, a zákonom zachovania momentu hybnosti, ktorý taktiež nemôže byt zmenený vnútornými silami. To znamená, že pohyb tela v letovej fáze je daný charakteristikami odrazu a po ukončení odrazu už športovec nedokáže zmenit pohyb tažiska ani vel'kost' mo- 
mentu hybnosti. Môže však zrýchlovat’ a spomalovat rýchlost’ rotácie na základe zmeny polomeru otáčania. Točivost' však musí byt daná odrazom.

Kedže pre gymnastiku sú typické rotácie vo vzduchu okolo rôznych osí tela, technika odrazu je jedným z klúčových faktorov športovej výkonnosti v tomto športe. Na vznik rotácie je potrebné vytvorit dvojicu síl. Pre salto vpred vzniká prvá sila rozbehom a druhá vznikne pri náskoku na mostík odrazom smerom hore a vzad (obr. 1). Práve sila odrazu smerom vzad spolu s rýchlostou rozbehu nám udáva moment zotrvačnosti, na základe ktorého telo vo vzduchu začne rotovat. Zložka sily pôsobiaca smerom hore nám udáva výšku skoku a rozdiel zotrvačnej sily vzniknutej rozbehom a zložky sily vzniknutej odrazom pôsobiacej proti smeru rozbehu nám udáva pohyb tažiska smerom vpred. Pre správne prevedie salta vpred je teda dôležitý správny pomer týchto síl v určitom čase.

Technika odrazu môže byt posudzovaná na základe prevedenia daného tvaru, alebo na základe záznamu odrazom vytvorených síl na dynamometrickej plošine. Posudzovanie kvality odrazu na základe okamžitých síl spolu s kinematickou analýzou pohybu s úspechom použili (Feč, K., Feč, R., 2003).

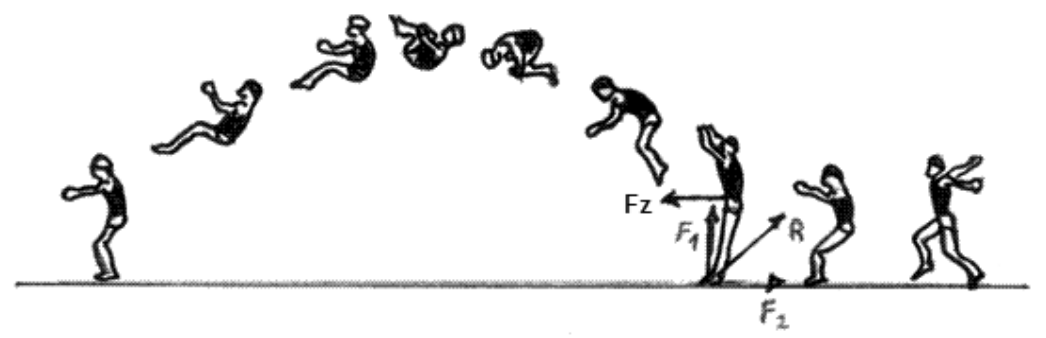

Legenda: $\mathbf{F z}$ - zotrvačná sila pôsobiaca smerom vpred, ktorá vznikla na základe odrazu, $\mathbf{R}$ - výslednica reakcie sily opory, ktorá vznikla odrazom cvičenca od podložky smerom hore a vzad, $\mathbf{F}_{1}$ - zložka sily reakcie opory pôsobiaca smerom hore, $\mathbf{F}_{2}$ - zložka sily reakcie opory pôsobiaca smerom vzad

Obrázok 1. Sily pri odraze a technika prevedenia salta vpred

Odraz trvá pomerne krátku dobu a volným okom nie je možné posúdit drobné odchýlky od správnej techniky. Smolevskij - Gaverdovskij (1999) uvádzajú, že gymnastické odrazy sa vykonávajú v priebehu 140-170 milisekúnd, a to v závislosti od fyzickej a technickej úrovne gymnastov. Preto vo vrcholovom športe má svoje uplatnenie použitie dynamometrickej plošiny, na základe ktorej je možné zosnímat krivky odrazom vytvorených síl a posúdit nedostatky v technike odrazu. Na posúdenie nedostatkov v technike odrazu je však potrebné vediet', ktoré parametre kriviek poukazujú na správnu techniku odrazu.

Odraz pozostáva $\mathrm{z}$ dvoch častí. Prvá je amortizačná, kedy svaly dolných končatín pracujú v excentrickom režime. V tejto fáze cvičenec brzdí vel'kost’ síl vzniknutých rozbehom a náskokom na mostík. $\mathrm{Na}$ krivke odrazu sa táto fáza prejaví najvyššími hodnotami vzniknutých síl. Druhá realizačná fáza začína až po dosiahnutí maximálnej hodnoty sily na krivke odrazu. Nárast a pokles síl na reálnych krivkách odrazu nie je postupný, ale vlnovitý. To znamená, že sila v priebehu odrazu narastá a klesá. To sa deje ako na krivke vertikálnej sily, tak aj na krivke horizontálnej sily.

Prevedenie salta vpred sa deje po predchádzajúcom náskoku na dynamografickú plošinu. To znamená, že počas odrazu sa telo pohybuje smerom vpred. Pre správnu techniku odrazu je potrebné generovat určitý pomer síl v horizontálnej a vertikálnej rovine. Aby športovec mohol maximalizovat’ jednotlivé zložky síl v najvhodnejšom pomere, musí ich generovat vo vhodnom čase odrazu, kedy poloha jednotlivých článkov tela dovolí produkovat tieto sily v optimálnom pomere.

Kedže charakteristiky letu sú určované impulzom sily, zaujíma nás, či je možné na základe časových charakteristík realizačnej fázy odrazu usudzovat' na kvalitu skoku. 


\section{Metodika}

Cielom výskumu bolo zistit, či je možné na základe časových charakteristík v realizačnej fáze odrazu posúdit kvalitu skoku.

Predpokladáme, že niektorý zo sledovaných časových ukazovatel’ov v realizačnej fáze bude štatisticky významne korelovat's počtom bodov za salto vpred a tým predstavovat potenciálny ukazovatel' správnej techniky odrazu.

Nezávislú premennú v našom výskume predstavovali časové ukazovatele odrazu. Závislú premennú predstavovala technika prevedenia salta vpred. Na sledovanie kriviek odrazu sme použili dynamografickú plošinu od firmy FTRONIC, spol. s. r. o. so softvérovým programom FORCE PLATE TWO CHANNELS z roku 2000, ktorá sníma priebeh síl v horizontálnej a vertikálnej rovine. Pokusné osoby tvorilo 13 študentov fakulty športu, ktorých úlohou bolo vykonat salto vpred po rozbehu s náskokom na dynamografickú plošinu. Techniku skoku sme zaznamenali na kameru. Tá bola neskôr obodovaná z desiatich bodov trénerom športovej gymnastiky prvej triedy (premenná 7). Pri bodovaní sme brali do úvahy celkové prevedenie salta so zameraním sa na výšku skoku a rýchlost̉ rotácie, pretože tieto parametre sú ovplyvnené technikou odrazu. Desat bodov predstavovalo najkvalitnejšie prevedenie skoku.

Na krivke odrazu sme sledovali tieto nezávislé premenné (obr. 2):

1. Celkový čas odrazu $(\mathrm{t})$

2. Čas od dosiahnutia maximálnej sily vo vertikálnej rovine po ukončenie odrazu (t-tFvmax)

3. Čas od dosiahnutia maximálnej sily v horizontálnej rovine po ukončenie odrazu (t-tFhmax)

4. Pomer času od dosiahnutia maximálnej sily vo vertikálnej rovine po ukončenie odrazu k celkovému času odrazu ((t-tFvmax) : $\mathrm{t})$

5. Pomer času od dosiahnutia maximálnej sily v horizontálnej rovine po ukončenie odrazu k celkovému času odrazu ((t-tFhmax) : $\mathrm{t})$

6. Pomer času od dosiahnutia maximálnej sily vo vertikálnej rovine po ukončenie odrazu k času od dosiahnutia maximálnej sily v horizontálnej rovine po ukončenie odrazu (t-tFvmax) : (t-tFhmax)

Premenná 7 predstavovala závislú premennú, na základe ktorej sme posudzovali kvalitu prevedenia salta vpred (počet bodov za salto vpred).

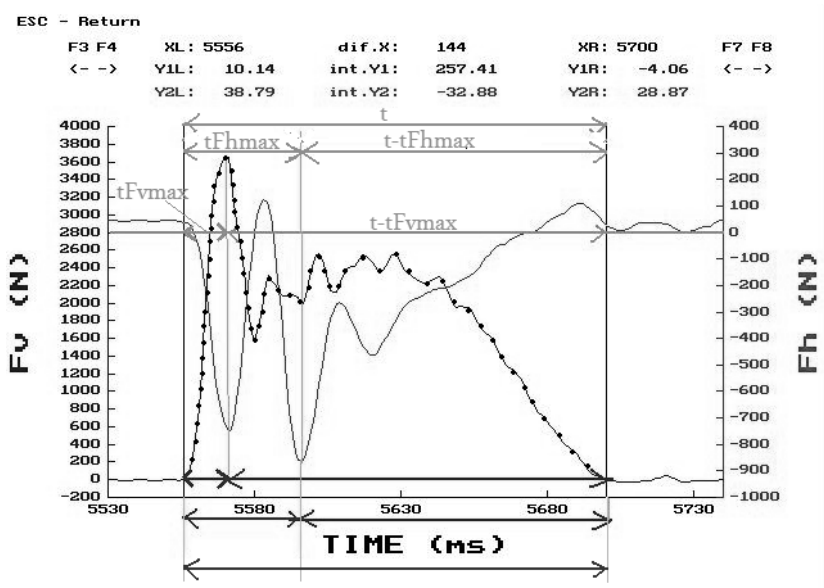

Legenda: $\mathbf{t}$ - celkový čas odrazu, t-tFvmax - čas od dosiahnutia maximálnej sily vo vertikálnej rovine po ukončenie odrazu, t-tFhmax - čas od dosiahnutia maximálnej sily v horizontálnej rovine po ukončenie odrazu, tFvmax - čas, dokial vertikálna zložka sily dosiahla svoju maximálnu hodnotu, tFhmax čas, dokial horizontálna zložka sily dosiahla svoju maximálnu hodnotu, bodkovane je vyznačená krivka sily Fv

Obrázok 2. Dynamografický záznam priebehu horizontálnej a vertikálnej zložky sily s vyznačením časových úsekov, ktoré sa dávali do vzájomných vztahov 
Ako metódu na posúdenie nakolko časové ukazovatele predstavujú indikátor správnej techniky sme použili Spearmanov korelačný koeficient medzi príslušným pomerom časového priebehu síl a kvalitou prevedenia skoku vyjadreným počtom bodov. Za štatisticky významnú hodnotu korelačného koeficientu budeme považovat $\mathrm{p} \leq 0,05$.

\section{Výsledky}

Priemerný celkový čas odrazu (premenná 1) bol t = 149,77 ms (Tab. 1). Podla korelácie premennej 1 so závislou premennou 7 (body za salto vpred) $\mathrm{r}=0,29$ (tab. 2) môžeme konštatovat', že celkový čas odrazu nie je vhodným indikátorom správnej techniky odrazu a kvality skoku.

Priemerný čas realizačnej fázy odrazu bol t-tFvmax $=101,69 \mathrm{~ms}$ (premenná 2 ). Táto premenná štatisticky významne korelovala so závislou premennou 7 (počet bodov za salto vpred) $r=0,58$. Pravdepodobnost' omylu, že existuje korelácia medzi týmito premennými v základnom súbore, je $\mathrm{p}=0,037571$. Daná premenná dokáže vysvetlit $34 \%$ z celkového rozptylu techniky skoku. Vzhladom na nízke percento vysvetleného rozptylu neodporúčame používat túto premennú ako indikátor správnej techniky odrazu.

Tabulka 1 Priemerné hodnoty sledovaných časových charakteristík síl vo vertikálnej a horizontálnej rovine

\begin{tabular}{|c|c|c|c|c|c|c|c|}
\hline $\begin{array}{c}\text { Č́śslo } \\
\text { premennej }\end{array}$ & 1 & 2 & 3 & 4 & 5 & 6 & 7 \\
\hline $\begin{array}{c}\text { Značka } \\
\text { premennej }\end{array}$ & $\mathrm{t}$ & $\mathrm{t}$-tFvmax & t-tFhmax & $(\mathrm{t}-\mathrm{tFvmax}): \mathrm{t}$ & $(\mathrm{t}-\mathrm{tFh} \max ): \mathrm{t}$ & $\begin{array}{c}\text { (t-tFvmax): } \\
\text { (t-tFhmax) }\end{array}$ & Body \\
\hline $\begin{array}{l}\text { Hodnota } \\
\text { premennej }\end{array}$ & 149,77 & 101,69 & 113,54 & 0,67 & 0,76 & 0,91 & 4,54 \\
\hline
\end{tabular}

Legenda: $\mathrm{t}$ - celkový čas odrazu, t-tFvmax - čas od dosiahnutia maximálnej sily vo vertikálnej rovine po ukončenie odrazu, t-tFhmax - čas od dosiahnutia maximálnej sily v horizontálnej rovine po ukončenie odrazu, (t-tFvmax) : $\mathrm{t}$ - pomer času od dosiahnutia maximálnej sily vo vertikálnej rovine po ukončenie odrazu k celkovému času odrazu, (t-tFhmax) : $\mathrm{t}$ - pomer času od dosiahnutia maximálnej sily v horizontálnej rovine po ukončenie odrazu k celkovému času odrazu, (t-tFvmax) : (t-tFhmax) - pomer času od dosiahnutia maximálnej sily vo vertikálnej rovine po ukončenie odrazu k času od dosiahnutia maximálnej sily v horizontálnej rovine po ukončenie odrazu, Body - počet bodov za salto vpred

Premenná 3 - čas od dosiahnutia maximálnej sily v horizontálnej rovine po ukončenie odrazu bol $\mathrm{v}$ priemere 113,54 ms (Tab. 1). Tento čas bol v priemere dlhší ako pre premennú 2 . Táto premenná nevykazovala štatisticky významnú koreláciu $r=-0,08$ (Tab. 2). Táto korelácia sa blížila k nule, čo znamená, že dľžka časového úseku od generovania maximálnej sily v horizontálnej rovine po ukončenie odrazu nesúvisí vo významnej miere s kvalitou odrazu.

Premenná 4 (pomer času od dosiahnutia maximálnej sily vo vertikálnej rovine po ukončenie odrazu k celkovému času odrazu) vyjadruje percento času do dosiahnutia maximálnej sily po ukončenie odrazu z celkového času odrazu. Táto hodnota predstavovala 67\%. Táto premenná taktiež berie do úvahy dva časové parametre. Korelácie tejto premennej so závislou premennou 7 (počet bodov za salto vpred) je $\mathrm{r}=$ 0,86 . Tento korelačný koeficient je štatisticky vel’mi vysoko významný $\mathrm{p}=0,000155$. Táto premenná dokáže vysvetlit $74 \%$ rozptylu kvality techniky salta vpred. Kladná hodnota korelácie so závislou premennou pre premennú 4 znamená, že čím dlhší čas trvá fáza od dosiahnutia maximálnej sily vo vertikálnej rovine po ukončenie odrazu z celkového času, tým je technika odrazu na vyššej úrovni. To zistenie korešponduje z fyzikálnymi zákonmi, pretože hybnosţ telesa sa rovná impulzu pôsobiacej sily, ktorý je závislý na vel'kosti sily a času, po ktorý sila pôsobí. 
Posudzovanie kvality odrazu pri salte vpred na základe časových charakteristík okamžitých síl na krivkách odrazu vo vertikálnych a horizontálnych rovinách v realizačnej fáze

Tabul'ka 2. Spearmanové korelačné koeficienty medzi jednotlivými skúmanými premennými

\begin{tabular}{|l|c|c|c|c|c|c|c|}
\hline $\begin{array}{l}\text { Č́́slo } \\
\text { premennej }\end{array}$ & 1 & 2 & 3 & 4 & 5 & 6 & 7 \\
\hline $\begin{array}{l}\text { Skratka } \\
\text { premennej }\end{array}$ & $\mathrm{t}$ & $\mathrm{t}$-tFvmax & $\mathrm{t}$-tFhmax & $(\mathrm{t}$-tFvmax) $: \mathrm{t}$ & $(\mathrm{t}$-tFhmax) $: \mathrm{t}$ & $\begin{array}{c}\text { (t-tFvmax) }: \\
(\mathrm{t}-\mathrm{t} F h m a x)\end{array}$ & Body \\
\hline $\mathrm{t}$ & 1 & 0,73 & 0,46 & 0,37 & 0,08 & 0,21 & 0,29 \\
\hline $\mathrm{t}$-tFvmax & 0,73 & 1 & 0,41 & 0,83 & 0,16 & 0,66 & 0,58 \\
\hline $\mathrm{t}$-tFhmax & 0,46 & 0,41 & 1 & 0,02 & 0,87 & $-0,26$ & $-0,08$ \\
\hline (t-tFvmax) $: \mathrm{t}$ & 0,37 & 0,83 & 0,02 & 1 & $-0,17$ & 0,92 & 0,86 \\
\hline (t-tFhmax) $: \mathrm{t}$ & 0,08 & 0,16 & 0,87 & $-0,17$ & 1 & $-0,40$ & $-0,36$ \\
\hline $\begin{array}{l}\text { (t-tFvmax) }: \\
\text { (t-tFhmax) }\end{array}$ & 0,21 & 0,66 & $-0,26$ & 0,92 & $-0,40$ & 1 & 0,82 \\
\hline Body & 0,29 & $\mathbf{0 , 5 8}$ & $-0,08$ & $\mathbf{0 , 8 6}$ & $-0,36$ & $\mathbf{0 , 8 2}$ & 1 \\
\hline
\end{tabular}

Legenda: $\mathrm{t}$ - celkový čas odrazu, t-tFvmax - čas od dosiahnutia maximálnej sily vo vertikálnej rovine po ukončenie odrazu, t-tFhmax - čas od dosiahnutia maximálnej sily v horizontálnej rovine po ukončenie odrazu, (t-tFvmax) : $\mathrm{t}$ - pomer času od dosiahnutia maximálnej sily vo vertikálnej rovine po ukončenie odrazu k celkovému času odrazu, (t-tFhmax) : $\mathrm{t}$ - pomer času od dosiahnutia maximálnej sily v horizontálnej rovine po ukončenie odrazu k celkovému času odrazu, (t-tFvmax) : (t-tFhmax) - pomer času od dosiahnutia maximálnej sily vo vertikálnej rovine po ukončenie odrazu k času od dosiahnutia maximálnej sily v horizontálnej rovine po ukončenie odrazu, Body - počet bodov za salto vpred. Hrubo sú vyznačené štatisticky významné korelačné koeficienty.

Premenná 5 (pomer času od dosiahnutia maximálnej sily v horizontálnej rovine po ukončenie odrazu k celkovému času odrazu) vyjadruje percento času od dosiahnutia maximálnej horizontálnej sily z celkového času odrazu. Táto hodnota predstavovala $76 \%$. Z tabul'ky je zrejmé, že táto premenná nepredstavuje vhodný indikátor techniky odrazu $(\mathrm{r}=-0,36, \mathrm{p}=0,232083)$.

Premenná 6 pomer času od dosiahnutia maximálnej sily vo vertikálnej rovine po ukončenie odrazu k pomeru času od dosiahnutia maximálnej sily v horizontálnej rovine po ukončenie odrazu dosiahla v priemere hodnotu 0,91 . Táto premenná korelovala so závislou premennou $7 \mathrm{r}=0,82$. Tento korelačný koeficient je štatisticky vel'mi vysoko významný $\mathrm{p}=0,000611$. Premenná dokáže vysvetlit $67 \%$ rozptylu kvality prevedenia skoku. Kladná hodnota korelačného koeficientu znamená, že čím je hodnota premennej vyššia, tým je vyššia aj kvalita odrazu. Aj táto premenná môže poslúžit ako indikátor správnej techniky odrazu.

\section{Záver}

Záverom môžeme konštatovat, že hypotéza sa nám potvrdila. To znamená, že je možné na základe časových charakteristík v realizačnej fáze odrazu posúdit jeho kvalitu. Štatisticky významné premenné zoradené od najvýznamnejšej sú: premenná 4 (pomer času od dosiahnutia maximálnej sily vo vertikálnej rovine po ukončenie odrazu k celkovému času odrazu), premenná 6 (pomer času od dosiahnutia maximálnej sily vo vertikálnej rovine po ukončenie odrazu k času od dosiahnutia maximálnej sily v horizontálnej rovine po ukončenie odrazu), premenná 2 (čas od dosiahnutia maximálnej sily vo vertikálnej rovine po ukončenie odrazu).

Silové krivky odzrkadlujúce kvalitu odrazu boli získané na študentoch a môžu byt' kvalitatívne odlišné od kriviek vrcholových gymnastov, pre ktoré môžu platit iné zákonitosti, ako pre krivky získané na študentoch. Preto je potrebné vykonat další výskum na potvrdenie týchto záverov. Podobnú analýzu by bolo možné taktiež využit aj v iných športoch, ako napríklad skok do výšky, alebo do dial'ky, kde generovanie síl v správnom čase ovplyvňuje trajektóriu tažiska, a tým aj výšku alebo dĺžku skoku. 


\section{Literatúra}

FEČ, K., FEČ, R. Prognózovanie výkonnosti v akrobatických skokoch v športovej gymnastike na základe biomechanickej analýzy techniky odrazu. In: Telesná výchova a šport v tretom tisícročí. Prešov: PU v Prešove FHPV, KTVŠ 2003. S. 62, 70. ISBN 80-8068198-8.

SMOLEVSKIJ, V. M., GAVERDOVSKIJ, S. K. Sportivnaja gimnastika. Kijev: Olimpijskaja literatura, 1999. 456 s. ISBN $966-7133-15 x$ 